\title{
The Conflict between traditional Cultural Praxis and Christian Faith: A Discourse of Oshiri Community in Onicha Local Government Area of Ebonyi State
}

\author{
Ukpa Uche-Egbulam \\ Department of Religion and Human Relation, Faculty of Arts, Nnamdi Azikiwe University, Nigeria
}

Copyright $(2019$ by authors, all rights reserved. Authors agree that this article remains permanently open access under the terms of the Creative Commons Attribution License 4.0 International License

\begin{abstract}
Oshiri community is one of the five communities that make up Onicha Local Government in Ebonyi State. Oshiri community inherited her traditional practices from her great grand founders. Christianity came into the Oshiri community after the settlement of the first people that arrived Oshiri. In Oshiri, they started developing cultures and other traditions which forms the culture of Oshiri people this day. In the later time, Christianity came-in with its own culture contradicting Oshiri cultures, and on several occasions, Christians in Oshiri abhor the tradition of the land intentionally Vis-versa. It is on this that this research focuses on the conflict between traditional praxis and Christian faith in Oshiri community. Specifically, does cultural praxis of Oshiri community actually conflicts with Christian faith in the area? This is the research problem which this research has been able to discuss. This research has been able to investigate the culture of Oshiri people, their marriage life, their economy and business life, their socio-political organization and lots more. Also, the research discusses various traditional practices of Oshiri people and how such praxis conflict with the faith of Christians. The research paper anchored on the religious pluralism and social learning theory, on the application this research adopted a descriptive phenomenological method with respect to the history and tradition of Oshiri people. The research concluded that some of the cultural practices of Oshiri people like marriage system, Aju and new yam festivals, age grade system conflict with the faith of the Christians in the area. Meanwhile, if both Christians and traditional adherents will come to understand the differences in the belief system, practices and the way each group understand its own religion, it will help the people to work together without having any misconception. Also, enlightenment and good understanding among the people will help in the unity of traditional adherents and Christians in Oshiri community.
\end{abstract}

Keywords Phrases, Oshiri, Oshiri Community,
Conflict, Traditional, Culture, Praxis, Christian Faith, Onicha Local Government, Ebonyi State

\section{Introduction}

Culture is a unique pattern of life of a people, thus a totality of group experiences, thought patterns, actions, practices, skills and behaviours learned and shared by belonging to a social unit. It comprises the language the people speak, clothes they wear, types of houses they build, their artistic creations, music, songs, literature, arts and craft, customs and institutions, type of government they have, technology and even their sense of humour. Hernlund (2001) posits that "culture is a totality of the way of life evolved by a people in their attempt to meet the challenges in their environment" ${ }^{\prime[1]}$. Since the advent of Christianity in Africa, both have been disagreeing with each other in some areas. Cultural practices and Christian faith have been conflicting with each other for years now in Oshiri community to the extent that both Christians and traditional adherents denied each other some vital rights like marriage and in sharing of land, and food within the clans. And for some time now, this issue has attracted serious attention as it affects the people's well-being. One cannot be a Christian, and at the same time a traditionalist. It is a complete and total hypocrite to be a Christian and at the same time a traditional adherent. One cannot be partaker of Jesus' communion and also a partaker in the Kolas and wine poured for libation or sacrifices to Idols vice-versa. Appleby (2001) says that "the power of one's worldview lies in the fact that it is hidden. It is a collection of one's underlying beliefs and assumptions which colour all its thinking, yet is rarely examined openly" $(\mathrm{p} .15)^{[2]}$. Appleby has rightly observed that what people believe today cannot be vividly analysed since its origin cannot be explained. Joshua (2010) reiterates that "in our societies today, 
traditionalists, see the Christians violating the ancient way of life of the ancient empire while the Christians see the traditionalists as sinners only because they do not adhere to the teachings of the New Testament of the Bible" (p.121) ${ }^{[3]}$. Some culture and tradition has always remained resolute against evil practices and would condemn the perpetrators of evil, while Christian religion has advocated for love of one's neighbour. Both traditional culture and Christianity are interwoven in their respect of goal seeking. To Christians, a traditional practice is considered sinful when rituals like pouring of libation and sacrifices to the $\operatorname{god}(\mathrm{s})$ are involved. Right from the unset, it has been a difficult task for mankind to be separated from his tradition since it constitutes their beliefs and practices. For decades, culture has been the mark of identification of every community. A man is identified based on his traditional beliefs. Some traditional practices in Oshiri may look mysterious in its praxis while other traditional practices may look simple, but the point is that all of them have a string attached to it. Culture remains the oldest thing in the Oshiri community, it can be dated around the existence of the first people who existed in the area like Akpata-Eze the great-grandfather of Oshiri, and the four sons and grandchildren. Christianity in Oshiri community spread with the help of the people's culture. This research makes reference to the history of Oshiri people, their cultural heritage and some of the areas the tradition of Oshiri community conflict with the belief and faith of Christians in the community.

Specifically, does traditional praxis of Oshiri community actually conflicts with Christian faith in the area? This is the research problem that has been given a close and careful attention in this research. This research will also investigate the culture of Oshiri people which include their marriage life, age grade system, new yam festival and Aju festival. In this research, how the mentioned praxis conflict with the faith of Christians will be explored. The traditional praxis of Oshiri people has crept in to disturb the natural desires of people who want to worship God with all their strength and hearts without paying any allegiance to any contradictory acts of the culture. The law for freedom of worship and movement are being thrown overboard by the current trends. Some people who may be interested in becoming Christians are restrained by these cultural acts.

Based on the problems generally facing Christianity and traditional practices in Oshiri community, the researcher chose to carry out this research with the following objectives: to explore the origin of Oshiri people. To state the impact of traditional praxis on the socio-economic well-being of Oshiri people. This research as well investigated the aspects in which cultural practices of Oshiri community disagree with the faith of Christians in the area and how it could be harnessed for peace, unity and development of the people. This research aims to suggest the place of Christians in the traditional practices of Oshiri people. This research also aims at creating understanding to Christians on how to handle the issue of cultural prejudice against their faith, and also to the traditionalists about the faith of Christian, so that no party will encroach on the boundary of the other.

This research is significant because it will proffer solutions to the conflict that exists between the traditional cultural practice of Oshiri people and Christian's belief. In other words, this research will broaden the horizon of the readers, to be faithful in their belief and not seeing the belief of others as evil. The contemporary society will benefit a lot from this research, as it will go to help correct the wrong beliefs of people in different cultures. It will also proffer alternative approaches to make one's belief adaptable to other beliefs. The research as well proffers solution to the socio-religious conflict in the contemporary time.

The scope of this study is limited to the sixteen villages in Oshiri community. The villages are: Umuorie, Umuimam, Agbabi, Isinkwo, Umumgbala, Isieke, Amaokpara, Mboji, Iyiazu, Ufuezokwu, Amankalu, Umumboke, Amaocha, Owom, Amaegu and Umuefia, all in Oshiri community.

The choice of methodology depends to a large extent on the nature of the work. The study, therefore, will be approached in a multi-dimensional way. In order to realize the purpose of this research, the researcher makes use of a descriptive phenomenological method which aims at getting information on the conflict between cultural praxis and Christina faith in Oshiri. In this research, data are gathered from primary sources which include personal communication, interview and secondary sources which include textbooks, journals and internet sources related to the topic.

This research anchored on the religious pluralism, and social learning theories. The findings from the research state that some of the cultural practices of Oshiri people like marriage system, Aju and new yam festivals, the issue of age-grade system and other practices conflict with Christian's faith in the community. Likewise, the practices of Christians conflict with the belief of traditional adherents as Christians forbid to abide by some norms of the traditional people. The research concludes by recommending that if both Christians and traditional adherents will come to understand the differences in the belief system, practices and the way each group understand its own religion, it will help the people to work together without having any misconception. Also, enlightenment and good understanding among the people will help in the unity of traditional adherents and Christians in the community.

\section{Conceptual Framework}

Every community has a particular way of life that is traceable to the origin of the community. Oshiri traditional 
or cultural practices are traceable to the origin and history of the community. According to Aja Chima (personal communication, 13th January, 2011), both Oshiri, Onicha Igboeze, Ukawu and Abaomege are the four Community out of the five autonomous communities in Onicha Local Government, that could trace their ancestral origin to Ezza in Ebonyi State. Nwangama (2011) reiterates that "oral traditions corroborated with anthropological evidence confirm that Ezekuna was the founder and legendary ancestor of Ezza people" (p.243) ${ }^{[4]}$. Ezekuna's father was said to be Ekumaenyi whom Ugoh (2003) confirms "was reputed to be a huge man of stiff military bearing, he had a quick intelligent mind, great personal charm and iron will" (p.20) ${ }^{[5]}$. It should be noted that very little is known about Ekumaenyi's personality. Oral tradition, however, according to Afoke and Nworie (2010) believe that "Ekumaenyi is the grandfather of Ezza, Izzi and Ikwo people. Ekumaenyi gave birth to Ezekuna, Olodo and Noyo who were the ancestral fathers of Ezza, Izzi and Ikwo respectively" (pp. 10-11) ${ }^{[6]}$. This is indeed the origin of the name of the three communities: Ezza-Ezekuna, Izzi-Olodo and Ikwo-Noyo.

The Oshiri community was founded by Ugo-Eze who is one of the brothers of Noyo of Ikwo based on the account of oral tradition. This Ugo-Eze according to oral tradition is the half-brother of Igbo-Eze who later is known as Onyikwa who happens to be one of the eight sons of Ezekuna. Onyikwa Igbo-Eze was a hunter by occupation and due to the lucrative nature of his hunting business, which took him across a big river (Ebonyi River) demarcating his hometown from the other side. After crossing the Ebonyi River, due to huge production in the area, he erected three different huts giving each a wide distance from another. The first hut erected was later left for the half-brother Ugo-Eze where today is known as Oshiri, the second hut erected was for himself which today is known as Onicha Igbo-Eze and the third hut erected was later left for Ikefi his junior brother who later founded a place which today is called Nkerefi in Nkanu West Local Government Area of Enugu State. Due to bountiful harvest in the area, Onyikwa Igbo-Eze left for the half-brother Ugo-Eze the first hut he erected. Oyikwa Igbo-Eze used this to settle the half-brother to ensure that he has a work to make a living. Ugo-Eze after his settlement in Oshiri went back to his clan and married and gave birth to Akpat-Eze. From the oral tradition, the name "Oshiri" was derived from the name "Osimiri" which also is as a result of Ugo-Eze's re-collective experience of crossing a big river called Ebonyi with the half-brother Onyikwa Igbo-Eze. Oral traditions have it that a powerful water animal called Crocodile (Aguiyi) could not harm Igbo-Eze. It is as a result of this that made Oshiri people forbids the killing and eating of Crocodile (Aguiyi). Today, the ancestral link between Oshiri, Onicha, Nkerefi and Ikwo is symbolized by a life covenant forbidding any spilling of blood between the communities.
Since Akpata Eze was left from the family of Ugo-Eze, oral traditions have it that he had four children who are believed to have respectively founded the first-four oldest villages of the sixteen villages which make up Oshiri community. The remaining twelve villages are said to have been founded by the grandchildren of Akpata Eze. Of all the villages in Oshiri, each of which has a traditional village chief who presides over vital issues that concerns the villagers on behalf of the community King (Eze). The traditional praxis of Oshiri community could be traced back to the first people that lived in the area. The first four sons of Akpata-Eze are Orie who was named after the first and oldest village called Umuorie Oshiri, the second is Imam who is later named after the second oldest village called Umu-Imam Oshiri, the third person was Abi who also was named after the third oldest village called Agbabi Oshiri and the fourth person is Nkwo who as well was named after the fourth oldest village in Oshiri called Isinkwo Oshiri. All these people according to oral tradition were four sons of Akpata-Eze. Ancestral ties between the people of each of these sixteen villages are very visible in certain aspects of their traditional praxis, including observance of some common festivals and practices like age-grade pattern (that is initiation into manhood) known as (Iphuluvu) for male children and circumcision $(I b u-U v u)$ for female children, marriage system (ilunwanyi), new yam festival (Iriji Ophuhu), burial system (ili Odju) and worship in some common ancestral shrines. Linguistic proximity is another noticeable evidence between them. Oshiri people have a unique language and culture that differs from the language of the blood brothers as previously mentioned, and that made them special in both character, learning and accommodation of stranger

\section{Oshiri People and their Cultural Heritage}

Oshiri community has traditions that are very rich with values though some do not agree with the faith of Christians in some aspects. Making reference to the above fact, Mbagwu (2009) opines that "traditional cultural practice reflects values and beliefs held by members of a community or social groupings for periods often spanning generations" (p.1) ${ }^{[7]}$. Supporting this view, Ojua, Ishor and Ndom (2013) confirm that "not all cultural practices and beliefs in Nigeria are bad" (P.182) ${ }^{[8]}$. Oshiri culture is systematic in nature, that is, it is been practised following the outline prescription by the community ancient people. Some of the cultural heritage of Oshiri people are listed and discussed below.

\section{Marriage System of Oshiri People}

There are significant similarities in the marriage customs of Oshiri people with other communities who share the same parental heritage with them, for example, Onicha Igbo-Eze, Nkerefi, Abaomege etcetera. Oshiri people are 
partly endogamous and partly exogamous meaning that some people marry within while some marry outside the community as do many in other Igbo and African communities. Marriage in the twentieth century in Oshiri community serves among other functions, as a major source of labour recruitment for farm work. Affirming this, Marion, Nicolas and Jean-Marc (2017) say that "couples are formed if an excess of the public good is produced in the association" (p.2) ${ }^{[9]}$. Also, the selection of marriage partners was mainly the function of parents. Sandhya (2013) confirms this by adding thus "historically, parents play a major role in choosing marriage partners for their children and the custom continues in the world's developing countries today" (p.1) ${ }^{[10]}$. Relating the ideas and contributions of the above scholars to the situation of Oshiri people. There is no gainsaying that such as mentioned by Sandhya was not true of Oshiri people, it was in those days that parents play a key role in finding woman and husband for their children unlike now due to globalization. The former could not favour majority and that initiated the changes in the system.

In Oshiri community, the following are some of the traditional items of bride price they are: Yam $(J i)$, goats (Ewu), kola nuts $(\mathrm{Oji})$, tobacco (Ishi-Enwuru), and pots of palm wine (Ite-meh), baskets of coconut (Nkata-Okpokpo), snuff (Enwuru) and few other items. Money has little or no place in traditional marriage in Oshiri community. Marriage is preceded by a considerable period of courtship, during which the intended married couples studied and adjusted to each other. Dowry items in the pre-modern time in Oshiri consisted mainly of household items, particularly cooking utensils like mortar and pestle (Ikwe Yele-Ozju), soup-spoon (Eku-Ophe), house broom (Eehza-Ulo), soup-broom (Eehza-Ophe), soap (Nqha), clothing materials (Uwe), food items (Ngwa-nri), and other house equipment (Ngwa-Ulo) that will help the girls live comfortably as women in their husband's house. In Oshiri community, even if the man is not capable enough, but because of the girl going to another man's house, the parents and relative of the girl will take it upon themselves to ensure the family starts up with vital family house utensils simply to enable the couples to live comfortably as new established family.

The marriage customs of Oshiri people have been affected tremendously by the forces of globalization. Not only in preferred marriage (that is one in which an individual makes his own choice) but now taken over the prescriptive form in which items for bride price is aimed to benefit the family of girls. In the present time, some items for marriage rites ranges from shoes to clothing materials, cars, houses, landed properties, etcetera. What the researcher portray here is that a man who wants to marry boast of all he has acquired in life to really make a girl comfortable. Some girls as well, before saying yes to a man will only be interested to be sure that the man has all it takes for her to live comfortably. Wealth acquisition in marriage system of Oshiri people presently is the main focus to some family in disguise. Eze (2014) confirms that "it is globalization that was responsible for the destruction of these primitive cultural practices" (p.142) ${ }^{[11]}$. Eze is quite right in his view as globalization has rendered the will of God in marriage unfulfilled as women and men nowadays are more focus on the material acquisition of a man or woman before accepting the marriage proposal. Marriage partners are seen as chattels based on the present trend in Oshiri community and entire Igbo land. What the researcher mean here is that in the Oshiri community and other communities in Igbo land, the major point of consideration in marriage agreement is based on what the man or the woman has. Globalization has made some who were not opportune to be educated to consider marrying a graduate to help cover up their literate weaknesses. Initially, the objective of marriage centres on the strength of the woman and her ability to complement the man.

Meanwhile, despite the fact that money plays a greater role in marriage today than in the pre-modern time, marriage in Oshiri can be said to be systematic, and easy to come by when compared with what is obtainable in many other Igbo communities. Marriage in Oshiri is so due to how homely and lovely the people are. Oshiri people cherish and love a healthy relationship more than anything else, in as much as their daughters can be loved by a man. Oshiri people frown at men beating their daughters in marriage or humiliating them. Oshiri people frown at a woman who does not respects or submits to her husband. In Oshiri, parents teach their daughters how to respect men and how they should live with their husbands. The types of marriage practised in Oshiri which are on the increase in the area include polygamy for those who are not Christians, monogamy for Christian believers. The Christians choose this form of marriage as that is the prescribed order of the New Testament marital order where Jesus specifically made reference to a man leaving both parents to cleave to his wife (Mathew 19:5). In this teaching of Jesus Christ, the main emphasis is that a man is entitled to one wife likewise a woman to one man.

\section{The Concept of Farming and Warfare in Oshiri Community}

The children are taught about the environment, the practice of agriculture, and technical knowledge like how to build houses (Ikpu-Ulo), mat-making (Ikpa-Ute), Palm oil production (Ishi-Manu), salt production (Ishi-Unu), a weaving of baskets (Ikpa-Nkata) etcetera. They are taught athletic skills like hunting (Igba-Nta), fishing (Igbu-Nweema), swimming (Ivu-Mini), and dancing (Ite-Evu) etcetera. The children are also taught the art of warfare. In the Oshiri community, parents gather their children to teach them warfare strategies especially when there is a problem in the community. This is supported by the comment made by Green (1940) who affirms that: 
In Igbos traditional political system, there was no Igbo state, no central authority which welded the people into political whole, whereas the Igbo societies can take decisions, carry out such decision and in the event of war organize themselves against common enemy suggest the fact that there were a central authority and the state where people are organized for actions. $(p .113)^{[12]}$.

Generally, Oshiri people have a war-god called Ogbu-Enyanwu situated in Ebonyi River. This war god is sacrificed to every year to be able to fight for the people in time of war. Ogbu-Enyanwu (war-god) in Oshiri community is like a projected rocket once it leaves the shrine and inside it contains all kinds of animal sound, example: cockerel (Okokoro-Oku), bull (Oke-Ephi), and the sound of pounding with mortar and pestle. The movement in the air and with horrible sound shows that the Ogbu-Enyanwu is out for war and can never allow Oshiri people to be defeated in war no matter the number of soldiers with their sophisticated weapons. Another thing about the people is that every child born in Oshiri land and those born outside the community also receive from the parents the consciousness of enemies around and how to get rid of them. Oshiri people are known for their physical might, and confident like their great-grandfather Ugo-Eze.

\section{New Yam Festival (Iriji Ophuhu) in Oshiri Community}

According to Aja, Chima (personal communication, 13th January, 2011), Iriji festival usually take place annually between August ending and the first week of September. Iriji festival usually marks a transition from a period of famine to a period of harvest. The Iriji is a major milestone in the traditional calendar of Oshiri people. According to Obaji, Obasi Alias Nwoke Ezuike (Personal communication, 12th November, 2011), in Oshiri, the harvest of new yam is usually proceeded by some scarifies, while the arrival of new yam is usually celebrated. The people pay a special respect to yam which is also common practice among Igbo people. They do it this way because of the status accorded yam as the prince of crops in Oshiri-land.

Iri-ji festival is associated with wrestling competition on Eke day known as Mgba-Eke, and is been observed at Eke market square. Due to the importance attached to Eke Oshiri market, the community arranged it in a way that normal marketing activity takes place on Nkwo day. On this Nkwo day, the major marketing items are groundnut (Ashioko), melon seeds (Elili), African oil bean (Ugba) and other items. The above mentioned items are made available on this Nkwo day use in place of Eke day to mark Oshiri people's end of famine period called Ntagbu-Unwu in the land.

\section{Isu-Afa festival/Nefi-Oha in Oshiri Community}

This is another festival common in Oshiri community.
This usually done to usher in the new traditional year in October. During this period of the festival, rituals are made to gods so as to take care of the people as they enter into the new traditional year. Activities accompanying this festival is usually done by the oldest family in Oshiri. Among the festival that are observed by Oshiri people, they all involved rituals which involve the killing of fowls, goat, use of kola before shrines, and pouring of libation.

\section{Aju Festival in Oshiri}

In this festival every family, clan whether there is money or not even if it entails borrowing to buy local fowl for yearly sacrifice on ancestral graves and Goat, Dog or its equivalent which after which is roasted and cooked for consumption. Aju festival is another important festival in the area in which people living in different places come home for its celebration. It marks a form of communion with the people's ancestral spirits during which sacrifices are made to their ancestors. In every village in Oshiri at this period, people move to the central area of the clan one belongs in order to have a share of the meat killed on Eke day. This share of meat usually come up on Orie day which Oshiri normally called Orie-Aju. This sacred communion is very significant that families come out with what they have and is shared accordingly among the members of the clan, whether you are around or not you will have a share of meat. This very exercise is carried out in a small central hut at the middle of every compound called Ngidi, and inside the Ngidi found a small wooden object called Okwa which is used to share the meat to everybody in every family within the clan. This festival is usually held or usually comes up between the end of September and the first week of October each year. It is obvious that this communion exercise symbolizes unity and love among the people.

\section{Age-Grade System (Ito-Ogbo) in Oshiri Community}

Age-grade (Ito-Ogbu) is initiation in Oshiri community that qualifies a male child a full grown adult irrespective of one's age, and as well qualify the person into married life. This is common in Oshiri community. In preparation for this act, those who are due are prepared to go to Eke market with umbrella and other age mates with a hilarious song, drinks and land gun. It is the tradition of Oshiri people that while going to the market for the initiation, the participants will enter through any shortcut but must not be through the main road leading to the market, and it is on their return that they will come home through the main gate leading to the market. This event is being accompanied by serious jubilation by the age mates and some members of the clan. Some parents force their young children to do it before getting to the age of knowledge. Some have the notion that it is done in order to prove that the person has actually been circumcised (that is cutting of foreskin). Reason for male initiation into manhood in Oshiri is to qualify a male child a full-fledged man. 
The female age-grade system is been determined by circumcision. Circumcision here according to the tradition of Oshiri people mean scrapping of the clitoris of a female child, and after which the girl will be regarded as a full-grown girl and will be due to being given out for marriage. This rite qualifies a female child in Oshiri to be receiving a share of meat, and food, within a particular clan. Traditionally in Oshiri, a girl will not be given away for marriage as a wife until what is called Ntugba Nri Yele Iwa $I b u U v u$ has been performed, that is traditional rite perform for girls after female circumcision (brushing of the female clitoris). What this means is that there will be a ceremony the day a girl will come back from been circumcised. It is a time the relation of the family come around to eat and merry together. During this period so many things will be bought for the girl who is circumcised. Highlighting the objective of female circumcision, Egbe Juliana (personal communication, 15th January, 2018), posits that one of the purposes of female circumcision in Oshiri community is to curtail the excessiveness of females going after men. Cutting the clitoris will reduce their sexual urge. The researcher called this "men subordination" in the sense that women practice what will make a man feel dejected by his woman (wife). What the researcher mean here is that the woman will not have feelings for the man who married her as a wife and the woman is just like a firewood on the side of the man. The power of a woman to perform effectively during copulation is hidden in her clitoris, and the power of a woman to be enjoyed and valued by the husband is hidden in her clitoris. When you cut a woman clitoris, the reason for her to be loved, cherished, valued and admired by a man will reduce and grow with time to bring about division and problem in the marriage. These are the reasons why this practice is ungodly and should not be continued by those who are still on it.

In Oshiri community, if one failed to be initiated into age grade, he will be taken as a child irrespective of the person's age, even though he had married with grandchildren, when he dies, he will be buried like a child because he did not meet up with traditional rite of age-grade initiation. Another effect of circumcision is that anyone who is not initiated traditionally will not be qualified to receive any share within a particular clan. In other words, any male child in Oshiri community, if not initiated will not be allowed to marry in some families. This issue has deprived some Christian men of marrying the particular girls they have interest on in Oshiri community and if the love the boy has for the girl is intense, he will be left with no option than to get initiated on duress against his Christian faith. Such Christian men usually observe their own initiation early in the morning around $5.00 \mathrm{am}$, when he will not be seen by the pastor or elders of his church and possibly by members of the church. Some also observe it in the night when no one will see their face.

\section{Taboos $(A r u)$ in Oshiri Land}

Taboo comprises those things that form the don'ts of a particular culture. Macdonald (1978) says that "taboos have to do with the system of prohibitions connected with things considered holy or unholy" (p.1373) ${ }^{[13]}$. In Oshiri, most villages have one thing or the other they regard as taboo when done by any member of the village, for instance Umumgbala Oshiri worships and forbid the killing of fishes in their great water called Urani, John, Okoro Egbe (personal communication, 18th January, 2018) says that Agbabi Oshiri worships and forbids the killing of monkeys in their great forest called Ophia Agbabi, Ishinkwo worships and forbids the killing of Lion $(A g u)$, Amankalu Oshiri worships and forbids the killing of Antelope (Ele), Umuorie Oshiri worships and forbids the killing of Crocodile, Amaokpara Oshiri worships and forbids the killing of Lion, Mboji Oshiri worships and forbids the killing of Snake, Owom Oshiri worships and forbids the killing of Chimpanzee (Nkoro) respectively. Oshiri entirely forbids the killing/ eating of crocodile (Aguiye) and killing of green snake called Aka. In Oshiri some forest is made sacred that people are not allowed to enter there for hunting and fetching of firewood. Urani is territory that a woman who is on her period (Ino-lee Nso Nwanyi) is not allowed to enter to fetch water or else she will not conceive again and a child that is still crawling cannot be carried to pass inside it instead the child will not walk again. Following the same sequence, it is a taboo for a woman on her menstruation period in Oshiri land to pluck a pepper seed(s) (Mkpuru Ose) from the plant. If any woman on her menstrual period does that, the pepper tree will instantly die, down the root level. After the menstrual period if the woman plucks the seed the plant will not die.

It is a taboo in Oshiri for a married man to sleep with another man's wife and a married woman who has attained the full traditional rites does not dare sleep with another man who is not her husband instead the spirit of the land will descend on her till she confesses it. The spirit of Oshiri land can only hold at ransom any woman who has been traditionally initiated into what Oshiri people called "Iji-woku" that is the traditional marital bond. In this ritual, married couples are made to sit before the eldest man in the compound who is going to perform the ritual. The woman sends out her two legs while the man brings out only one of his legs. In this performance, the elderly man uses a local chick (Oku Odoh), and he will use it to touch their legs four-time symbolizing the four major market days that is Eke, Orie, Afor and Nkwo. After which they will kill the chick, roast it, cook and eat at the spot. Among those that will partake in eating the small meat, if you committed an atrocity like adultery, you do not even need to come around the place talk more of eating from the meat, instead, the spirit of the land will descend on you instantly and kill you. One may ask, why a man will bring out only one leg while the woman her two legs. It means that after the rituals, the woman is bound from having sexual affection with another man except for the husband she had the bond with, and if she consciously or unconsciously tries it, she will be 
knockdown by the spirit till when she confesses it. The one leg removed by the man means that he is free to have sex with another woman without the spirit of the land holding him captive. Also, the man is free to marry as many wives as he wishes to marry. As a feminist, I called this 'man's inhumanity to women'.

\section{Economy and Business Life of Oshiri People}

Oshiri is a periphery community meaning that they provide food and other materials resources which the centre (Urban) areas of Abakaliki, Eza, Onicha Igboeze, Isu Okoma, Ugwulangwu, Ukawu, Aba, Enugu, Onitsha in Anambra State and even beyond were been maintained and sustained. Some of the food and material resources produced by Oshiri people are: Rice, palm oil, Palm kernel, Basket (Nkata), all kinds of Yam, Cassava, mat-production, wine-taping, and mat-making (Ime-Ute) which has been the major source of income of most people in the area. And through the income that comes from the above mention sources, most of the houses in the area were built, vehicles, bicycles used in the area for quick transportation of the farm products to the market were bought, and most graduates so far were trained from the income of what the people produce. There are other natural minerals discovered in Oshiri waiting to be mined, example: Coal, granite, Zinc, sodium chloride 'salt' and others yet to be discovered. Oshiri people are blessed among other nearby communities in Ebonyi State in Nigeria.

\section{Oshiri People's Administrative Authority}

Oshiri council of elders has a unique system of resolving issues for the progress and wellbeing of the people. Public issues are resolved at Akpata-Eze (the compound of the oldest family in the oldest village in Oshiri). The original structure of Oshiri was built by strong, selfless people who do not feel it is necessary to pamper them. "Live and let live" (Egbe-bere Ugo-bere) has been a strong sense of self-reliance, a feeling that everyone is equal as it included "sue and resolutions" (Iku Ikpe lee Idojzi Ofu) when problems arise in the land. The administrative system is based on the cult of ancestors (Ndi Ichie) and the earth deities. The authority of the leaders of the kindred's (Ndi Ishi- Ifu) and Eze of the community is based on the fact that they are regarded as living in close association with the ancestors and was thus the chief repository of customs. The leaders are not autocrats for the members of the community, they are only to listen to their advice and carry it out when necessary. If they believe that they are correctly interpreting the wishes of the ancestors. The village/ clan leaders are the living founts of all authorities for the ancestors and the Eze is the channel of communication. In each village, the Ndi Ishi- Ifu were more concerned with solving the problems of their clan (Ifu), while the chiefs and Eze take care of matters that affect the whole community and also individual case that is beyond the clan leaders. Some people who encounter difficulties in making peace in their family unit consult their ancestors often with kola nuts and wine before peace would be achieved. Price Emenike Nwogo and Chief Eyeke Nwelebe (phone conversation, 13th January, 2018) reiterate that in Oshiri, the Eze by tradition depending on the nature of what is to be done can delegate his authority and responsibility to the son who is the prince or the prime minister. The Eze of Oshiri community perform the traditional prayers (Igo opho) during the communal gathering and with the help of subordinate chiefs from every village who formed his cabinet. Whatever they do are not questioned as much by the members of the community but they are careful not to offend the ancestors who had the concentrated power of government on them and whom they are accountable to. The administrative system of Oshiri community is organized in such a way that the chiefs and leaders of every clan are not permitted to engage in anything evil due to the fact that they are the ones who approach the ancestors ( Ndi ichie) on behalf of the people and they must be Holy always.

\section{Features and Social Structure of Oshiri People}

Oshiri is located about $330 \mathrm{~km}$ south of Abuja the capital of Nigeria. It is an area of highlands and hills of about 150 feet high. Such hills amongst others include: Owom hill. (Uvu Owom). Oshiri community has a smooth and gentle undulating topography. Thin belts and Small Island of closed forest. Though in Oshiri, most of the area varies from open wood to orchard bush and tall grass. The rainforest zone begins in the wet season, streams (Mgbawara/Ohda), Lakes (Ovu), River (Ebonyi) and others except for the large River (that is Ebonyi) and small but a mighty body of water called Urani dry up in the dry season. One notable international airport (Nnamdi Azikiwe International Airport is located about $52.1 \mathrm{~km}$ North-West of Oshiri town.

In Oshiri, each patrilineal villages has its homeland called (Ibe or Unuhu), where the head of the senior lineage (Okenye), other elders and their younger sons, daughters with their wives live. There also exist a large area of more recently acquired farmlands called $(E g u)$ over which the people allot for farming work. Settlements are sparse out and houses are roundly built and at time in square form with low walls, circular grass roofs (Ulo-Ephia) and a small veranda in front, they are set in a compound surrounded by a fence of sticks (Ogirishi) or mud walls and the entrance are tough clay porch, though due to civilization most of this setting is giving way for brick and modern houses.

\section{Theoretical Framework}

The theory according to Abend (2008) is a general proposition, or logically-connected system of general 
propositions, which establishes a relationship between two or more variables ${ }^{[14]}$. It is an explanation of a particular social phenomenon. A theory offers a general account of how a range of phenomena are systematically connected; by placing individual items in a larger context, it increases our understanding both of the whole and of the parts constituting the whole. The theory is a systematic, analytic approach to everyday experience. In this research two theories are used: Theory of religious pluralism and social learning theory.

\section{Theory of Religious Pluralism}

Since the publication of an Interpretation of religion in 1989, John Hick has become arguably the most important philosophical and theological exponent of religious pluralism in Anglo-American scholarship. His influential ability is doubted, yet it is considered that his opinions and ideas about religious pluralism is touching. The theory of religious pluralism focuses on the fact that all the religion in the world are all salvific and are leading towards similar transcendent reality. Comparatively, no religion is considered most salvific and most important than the other, all religion has particular goal and intent for their adherents.

\section{Social Learning Theory}

This is one of the most popular explanatory theory enunciated by Albert Bandura. This theory is a guiding framework for this research. This theory is facilitated through concepts like modelling and observational learning. Social learning theory is a theory of learning and social behaviour which proposes that new behaviours can be acquired by observing and imitating others. According to Bandura (1971), "it states that learning is a cognitive process that takes place in a social context and can occur purely through observation or direct instruction, even in the absence of motor reproduction or direct reinforcement" ${ }^{[15]}$.

\section{Areas of Conflict between Oshiri Cultural Praxis and Christian Belief in Oshiri Community}

The noticeable conflict between Oshiri cultural practices and Christian belief are explained as found in below areas:

\section{Aju Festival}

The most prominent of the conflict between culture and Christian faith in Oshiri community is found in Aju festival and the activities surrounding it. As explained earlier, Aju festival is the biggest and most celebrated festival in Oshiri community in Onicha Local Government Area in Ebonyi State. The climax of the celebration is on Orie day which is popularly called (Orie-Aju). The nature of this ceremonial day is such that no other market is allowed to operate on this day. The period of Aju-feast in Oshiri community, marked the time of communion between the living ancestors and the ancestral spirit under which the living ones offer sacrifices to the dead spirits. And on this occasion, Christians are persecuted by the Aju-festival adherents due to their forbidden concept to be part of the festival. This persecution emanates from the fathers to the children via the wive(s) who happened to be Christian(s). The Christians at this point insist that they will not touch any meat that is sacrificed to the idols or presented to the gods in the shrines.

\section{Relationship of Families during Aju-Festival in Oshiri Community}

During this period, there has always been a general hostility between the traditional men and their Christian wives and children. In Oshiri, the tradition has it that it must be the first wife of the man that will cook the Aju food (Nri-aju) for the family. The denial of this right from the adherents, in turn, restrict the fathers from carrying out some certain roles in the family like payment of children's school fees, buying them clothes and providing them food. The worst of it all is that some will go to the extent of sending their wives, children away from the house there-by exposing them to dangers. Also, holding to the fact that some women have run into Christianity that made most husbands be violent over their wives for refusing the responsibility on them. This effect has been the worst insubordination against the husband and his ancestors and in some cases has led to divorce. In an effort to make traditional wife do the cooking, the traditional husband exercised his superiority over the wife to the extent of strangulating the wife. This is done because the man will be taken as a weak man by his fellow men and even by his ancestors who would say he is an unworthy representative. In order to run away from this responsibility, such women and their children resorted to running to the church to hide for some period of time. Most churches in Oshiri has been led to keep night vigils at such night when these festivities are done, so as to keep the members safe from harm by their husbands and fathers. Some children have been abandoned together with their mother to fend for themselves and would have nothing in common with the fathers again. Many families have been torn apart during this period and are therefore generally known to be a period of family persecutions in Oshiri both to traditionalists and to the Christian in their faith. These two parties were not willing to listen to each other even in the family, one sees the other as the enemy of his/her progress. In the event of any evil occurrence in the land, the traditionalists would accuse the Christians that this happened because of the desecration of the land that such calamity has befallen them, whereas the Christians would accuse the traditionalists of being responsible for their set back because they patronize deities and idols and refused to repent. 


\section{New Yam Festival}

Another area of conflict is the area of the new yam festival. As said earlier on, Oshiri people's traditional year begins ending of August and the first week of September each year. It follows that at the end of the year and before the dawn of the traditional New Year, the oldest man in every family is to announce and usher-in the New Year, making some pronouncement and rituals on behalf of the family for the year. This rituals and pronouncements are made in the yam barn, at the base of Ogirishi tree.

There at the base of the tree, you will see small pot(s) containing concoctions representing a god called Njoku-Barn (Njoku-Oba). This is the origin of some people's sure name Njoku and Nwanjoku. This Njok-Oba is just a small earthen-pot with water and other mixtures as earlier mentioned. This god is regarded as the god responsible for yam bountiful productivity. Every compound in Oshiri community appeases this god every year. To appease it with cola nut, the blood of animal and wine means that the year yam produce is good and following year yam produce will be better. According to Obaji Obasi Alias Nwoke Ezuike (Personal communication, 12th November, 2011), "before in Oshiri community, nobody is expected to come out mid-night to meet face to face with the spiritual men during the traditional rites of ushering the new yam festival. And if a virgin girl mistakenly comes in contact with them, she will cease from childbearing (that is, she will become barren throughout her lifetime)". This being the case, some Christians chose to defy such tradition by hosting night vigil in their churches and going out from there for morning cry by such time as was forbidden for anybody to walk along the road. So, the activities involved in the practices of Oshiri cultural norms make it difficult for Christians to cease from functioning during this period. It means that Christians do the opposite of what some culture of Oshiri demands due to fetish art involved.

\section{Age Grade System (Itche-Ogbo)}

Age grade system marks another area of conflict between Oshiri traditional praxis and Christian's faith in the area. The Christians frown at it because of some activities in the Age Grade system which do not agree with their faith. For instance, most of their meetings usually fall on Sunday morning and some of the dances, songs and other activities which does not give glory to God were reasons why Christian disliked it. Examples of such song are:

Solo: Agbawu-atashio

Others: Ewo yara-wororo,

iyee-iyee (repeatedly).

The meaning of the song is that the person who is celebrating and also whom the song is going to is cursed with a dangerous sexually transmitted disease called 'Gonorrhea' (Atashi).
In other words, since the majority of the things they do are not Christian, a lot of damages has been caused due to absenteeism of some members to their meeting. Some families, brothers are no longer relating well due to the misunderstanding encountered during one of the Age Grade meetings. Seeing the evil nature of Age-grade, Ugbo (2009) confirms that:

\section{Unhealthy jokes and characters that may wound the Christian spirit are rampant in our age grade system. Fetish practices abound which often lure age mates to consult mediums, e.g. native doctors to settle those problems. In such situations, they make contributions to subsidize the venture. (p.103) [16]}

In concurring with the view of Ugbo, the same practices are applicable in the most age-grade system in Igbo-land. The age grade members go to the extent of moving to a member's house who did not meet up with the demand of the group and cease some household items, at the same time they beat up the person to stupor.

\section{Marriage Life}

Looking at the aspect of marriage in Oshiri community, Christian belief does not encourage and support a polygamous type of marriage rather they preach monogamy that is 'one-man-one -wife'. Some families today in Oshiri are divided as a result of no male child born in the family. On this, the man who is not a Christian may like to marry another wife just to ensure continuity of the lineage through the birth of a male child (children). This problem is intense especially when the first wife gives birth to only female children. In the family conflict of this form, the woman who is a Christian may not buy the idea with the husband who wants to go into another marriage with another woman. The woman will only be on the view that the husband is patience to wait on the Lord to give a male child (children) to the family. Since both Christians and traditionalists hardly see something wrong/right in this aspect of tradition, both need to pay attention to each other in order to understand and learn each other's perspective of reasoning. This advent of new wives in some homes has been too problematic to those who were there before the new wife. Again some Christian believers in Oshiri are also against using palm wine as a rite of marriage. It is not for anything than the fact that after getting drunk with palm wine, people go about fighting and some men go about fighting their wives and children for no reason. Sometimes a father of responsible wife and children will be found lying on a gutter just for being drunk. For the sake of unity and continuity of life, both Christians and traditionalist need to consider the theory of religious pluralism of which will take care of both parties understanding of the fact that both parties view are important. Also, on the side of the leaders in Oshiri community, they need to consider each 
other's faith and belief by mapping out Christian outline and list for marriage rite and traditional list for those that may like to take the path.

\section{Burial Ceremony}

Considering the burial rites accorded to death. Traditionally, when one dies in Oshiri community if the one death is suspected to be induced by someone, the family or relation of the diseased go to the extent of adding things like a broom, knife, phone, nail etcetera inside the casket of the dead person. The implication of this is for the dead person to be able to go and look for who killed $\mathrm{him} / \mathrm{her}$. Christians forbid all these practices as one cannot take vengeance rather God. In the same vein, gun shooting is another prevailing practice to the death. Sometime a well-known traditionalist may die, and the family been Christians may not allow such rites to be given to their father because to them it is a fetish in nature. Some families in disguise may go out and employ a man of God who will come and officiate the burial for the family. And the traditional adherents who already knew the importance of giving such rite to the man will come up at the scene insisting that some sacrifices, gun shooting and other traditional ceremonies must be observed in honour of the dead. This disagreement continues to the extent that both parties will start exchanging words, fighting, murmuring and even creating division among family members.

\section{Oath Taking (Ita-Mgbu)}

This is a crucial procedure for ascertaining the truth about a matter between two individuals or families. It is usually done when one has a disagreement between his fellow on land matters. In Oshiri culture, it is believed that when an Oath is taken, a sequel to the stipulated number of days, weeks, months, and years given for the oath to react, life is always taken as a result of its effect. But Christians are not in support of it even when they are involved in any mater that such should be done, because it is diabolic in nature, and cannot by any means help for the progress of families even the entire communities. Christian disagreeing vehemently with oath-taking, quote the bible as being against such, and that God will vindicate the just. Today some take advantage of Christians by imposing some crime on them as the cause of some evil action since they cannot accept taking oath on issues they are involved.

\section{Idolatry (Ikpere-Erishi)}

Idolatry is from the Greek word $\boldsymbol{\varepsilon} \boldsymbol{\imath} \boldsymbol{\kappa} \boldsymbol{\kappa} \boldsymbol{v}$ and it means likeness of someone or something, most often in another medium. Ferguson (1998) says "idolatry as a statue is a likeness of a great personage" (p.329) ${ }^{[17]}$. Idolatry practice in Oshiri is forbidden by Christians due to the fact that Christian's belief condemns it. In addition, Idowu (1973) reiterates that "the trouble about most approaches to subjects as delicate as this is that people tend to employ words in current use without due regard to their basic meanings" (p.122) ${ }^{[18]}$. Actually, people worship images due to its traditional nature without knowing the source and implication of it. Moreover, considering the impending statement on idolaters, Fuller (1994) affirms that:

Idolatry and worship of other god are called prostitution or harlotry in the bible. It is urging peoples love and devotion, which is supposed to be reversed for God alone on other beings unlawfully. A good passage on this is Jeremiah 3:6-14. That is why idolatry arouses God's jealousy and is one of the reasons why he wants all people delivered from the worship of false gods. (p.42) ${ }^{[19]}$.

Deuteronomy 27:15, says, "cursed is a man who carves an image or casts an Idol - a thing detestable to the Lord, the work of the craftsman's hands - and sets it up in secret" (NIV). Paul also warned that people who practice idolatry are among those who will not inherit the kingdom of God (Galatians 5:21).

One may ask 'how عוkóv does arouse conflict between Christians and traditionalist in Oshiri community? The conflict infliction is in the following way, a traditional man in a particular family urge one who is a Christian to ensure that he observes some traditional rites like sacrificing to the grave of the dead ancestors. When such is not done, the elderly man who happens to be a traditionalist will start having a serious problem with the Christian man. Most of the reason for sacrifices in the grave of the dead is simply for the dead ancestors to protect the living ones in the family. It is the belief of the traditionalist that the Christian man whose is now due to take over the responsibility is the one behind the problem of the family success.

\section{Ways Forward to Resolution of the Conflict between Traditional Praxis and Christian Faith in Oshiri Community.}

In an attempt to overcome conflict, Nwankwo (2002) posits that "there is no conflict that is without a solution, likewise, there is no trouble or problem that cannot be resolved. The solution of a problem or its resolution depends on the management principle applied to the said conflict" (p.79) [20]. With the courage given, it then stands to mean that there is a solution on how to overcome the prevailing trait of traditional practices and Christian faith in Oshiri community. Otite (1999) says that "conflict is a negative means not only of limiting people's desire and expectations, but also a way of promoting the happiness of individuals and groups in a plural society" (p.337) [21].

However, we are different from one another, but we are not distant from one another. Christians and traditional adherents need to learn much about each other. "Togetherness" that is active and proactive manner, will 
help both adherents to feel the need for the other. Unity of Christians and traditional adherents in Oshiri can be achieved through Benevolent Indifferent or with a sense of self Sufficiency, of a truth, this is no longer a faithful way of relating with each other. We all need to know more because our knowledge of the truth is only partial, at least. Truth is more than what we understand it to be or know it to be. A classic metaphor has been used to describe this situation. We are, each in our own religious traditions, like the five blind men who touched different parts of an elephant and described the elephant accordingly,

According to Thangaraj (1999), one touched the tail and said that the elephant looked like a giant brush, another felt the leg and thought that the elephant looked like a pillar and so on. They were all right in what they said, but only partially [22]. Religions are like this in the knowledge of the truth. All religious beliefs and views are only approximations of the truth. The only problem in this metaphor is that it implies there is no person who has seen the whole elephant, and that person is able to make the judgment that every vision is partial. Who could that person be? None of us who belong to these religions are in a position to have a look at the whole elephant and make a judgment. Nevertheless, the idea that our concepts, ideas, and views are only approximations is well taken. If that is the case, we do need that for our knowing more and for progressing toward the whole truth.

Secondly, another aspect under which this conflict could be overcome is by "TOLERANCE", according to Macdonald (1978), "tolerance has to do with the ability to endure, disposition or willingness to tolerate or allow a permissible range of variations" (p.1418) [13]. Fubara (2007) says that "one must listen to what the world has to say, it should as well be registered in our mind that a true religion is that one that is open to all, so that if there is any way they need amendment in their way of doing things that could be made" [23]. For things to work better, the Christians must listen to the traditionalist, and the traditionalist should as well listen to the Christians. Both parties should endeavour to study each other's area of weakness and strength so as to know how to approach each other. Ugbo (2009) opines that "Christians should bear with them. One thing is certain, that among two things one is greater and better" (p.111) [18].

Thirdly, in order to sail through in this problem, people need to be "EDUCATED", through education, people could be taught about the right in which an individual had in a given society. Considering the importance of education, Francesca and David (2015) reiterate that "education aids in the decision-making process" [24]. Level of one's enlightenment affects to a large extent the decision that person makes in life. Iwe (2002) in the voice of freedom posits that:

Every person shall be entitled to freedom of thought, conscience and religion, including the freedom to change his religion or belief and freedom, either alone or in community with others and in public or in private, to manifest and propagate his religion or belief in worship, teach, practice and observance. (p. 270) ${ }^{[25]}$.

Oshiri people need to be educated on how to tolerate and accommodate different people with different opinion and belief. And everyone in the area has to worship anything he/she likes without any external influence. Following this will help to eradicate religions conflict in Oshiri community. Considering the importance of dialogue in resolving the differences between traditional adherents and Christians in Oshiri, Anyacho (2009) says that "the ultimate goal of dialogue is to create an avenue through which peace can be promoted in the society" (p.163) [26]. In every step to attain a cultural level in Oshiri, there is a need for dialogue, and that should be with elderly consensus.

\section{Conclusions}

Culture has been discussed differently by different scholars. Culture with reference to what scholars said could be taken to mean way of life of a people, a way of life that reflects their distinctive genius and spirit, their fundamental character or ethos, their values orientations, worldview, institutions and achievements in various fields of human endeavours, legal and literary, artistic and scientific, religious, philosophical and technological. Christianity penetrated into Oshiri community through Oshiri culture, the culture of the people was of good help in making it effective. But along the line, some of the cultural practices like marriage system, festivals, the issue of age grade system and other practices began to conflict with the practices of the Christians in the area. This dialogue was not caused by anything other than the different belief of the people in various aspects of cultural praxis. In an attempt to quite the misconceptions between traditional praxis and Christian faith within the axis of Oshiri community, cultivation of the spirit of tolerance, been educated, togetherness and true knowledge will help to accommodate each other. Today in Oshiri community, most of the menace depicting Christian's faith is fashioned in a way that its solutions are defined. Considering the problem among culture and Christian faith in Oshiri, if both religions will come to understand the differences in a belief system, practices, and the way each group understand its own religion. It will be of good help for the people to work together without having any misconceptions. Therefore, both culture and Christianity can rub minds together to build up a peculiar society, if only they will both come to love each other, cultivate peace among themselves, going after the development of the community in terms of encouraging innovation and strengthening democracy. 


\section{Findings}

The following findings were made in the cost of the research:

- The traditional culture of Oshiri community denies any man who is not initiated into age grade (Iphuluvu) his vital rites in the clan and family via the community as a whole.

- Christians frown at some traditional praxis because of the rituals that are involved in its process.

- There will be strong unity of both Christian belief and traditional belief if only if both will understand the background of each other and respect each other as well.

\section{Recommendations}

Following the trend of behavioural approaches of traditional adherents in Oshiri community, the research recommends that:

- Two outlines are drafted as a procedure for marriage rites in Oshiri community; one for Christians and the other for traditional adherents.

- The issue of denying a man who has not been initiated into age grade (Iphuluvu) its rights be a thing of the past as that has nothing to contribute in the building capacity of youths and development in the community rather bringing intense shock on the emotion of young people of the community.

- Christians in Oshiri need to be accorded the rite of approaching the tradition of the people following the method that will not infringe on their own faith. For instance, using soft drinks for marriage rites instead of paying money for alcoholic drinks.

- Christians need to obedient to the traditional culture of the people in as much as that has nothing to do with their faith.

- Traditional adherents as well are to be open minded to go into dialogue and bearing in mind that both religions have a different method of handling their issues.

\section{REFERENCES}

[1] Hernlund, J. (2001). Women marriage in Africa: A critical study for gender and rights. Newzealand Journal of Sociology 17, 4, 32-40.

[2] Appleby, S. R. (2001). Religion, conflict transformation and peacebuilding. Washingon BC: CSIP Press.

[3] Joshua, P. \& Ohuabunwa, S. (2010). Reformation of Arochukwu tradition and Culture. Lagos: Real Value Trust.

[4] Nwangama E. U. (2011). The beliefs, practices and relevance of ancestral veneration in North-Eastern Igbo land, Nigeria. A thesis presented to the department of religion, University of Nigeria, Nsuka in partial fulfilment of the requirements for the degree of doctor of philosophy $(\mathrm{PhD})$ in African traditional religion, November, 2011.

[5] Ugo, C.N. (2003). Polytheism: The gods of Abakaliki a historio-religious link. Enugu:Handel Books.

[6] Afoke, J. N. and Nworie, P. M. (2010). Ezza history, culture and civilization. Enugu: Cidjap.

[7] Mbagwu, F. O. (2009). Assessment of the harmful cultural practices affecting the health of Rural Women: A study of community-based women organizations in Ebonyi State. A $\mathrm{PhD}$ Thesis presented to the department of adult education and extra-mural studies University of Nigeria, Nsukka. March 2009.

[8] Ojua, T.A, Ishor, D.G and Ndom, P.J. (2013). African cultural practices and health Implications for Nigeria rural development, in International Review of Management and Business Research, 2, 1, 176-183.

[9] Marion G, Nicolas J \& Jean-Marc R. (2017). Household labour supply and the marriage market In the UK, 1991-2008.Labour Economics, Elsevier, 2017, 46, pp.131-149. Retrieved on https://doi.org/10.1016/j.labeco. 2017.02.005.10.1016/j.labeco.2017.02.005.halshs- 014765 09 on January 22nd, 2017.

[10] Sandhya, S.J. (2013). Parental influence on mate choice criteria, in IOSR Journal of Humanities and Social Science, $15,2,1-4$

[11] Eze, D. (2014). Nigerian and the crisis of cultural identity in the era of globalization, in Journal of African Studies and Development 6, 8, 140-147.

[12] Green, M.M (1940). Igbo Village Affairs. London: N.A.

[13] MacDonald, A.M (1978). Chambers twentieth century dictionary: Britain: T \& AConstable.

[14] Abend, G. (2008). The meaning of theory. Washington: Northwestern University.

[15] Bandura, A. (1971). Special learning theory, general learning corporation retrieved from www.asecib.ase.ro 25 th December 2013.

[16] Ugbo, E.N. (2009). The value and dignity of life: Studies in religion and human value. Owerri: Whytem.

[17] Ferguson, S.B. (1998). New dictionary of theology. Iinosi: Intervarsity.

[18] Idowu, B. E. (1973). African traditional religion, a definition. Great Britain: SCM.

[19] Fuller, L.A. (1994). Missionary handbook on African traditional religion. Kaduna:Baraka.

[20] Nwankwo, C.K. (2002). Adequate training of Pastors. Port-Harcourt: Josany.

[21] Otite, O. \& Albert, I.A.Eds. (1999). Community conflicts in Nigeria: Management resolution and transformation. Ibadan: Spectrum Books.

[22] Thangaraj, T.M. (1999). Relating to people of other religions. Great Britain: Abingadon. 
[23] Fubara, M. (2007). In missio dei. Calaba: Presby Press.

[24] Francesca, M \& David, E.S. (2015). The role of education and family background in Marriage, childbearing and labour market participation in Senegal. Bonn: Iza.

[25] Iwe, N.S.S. (2002). Christianity, culture and colonialism in Africa. Calaba: Saesprint.

[26] Anyacho, E.O (2009). Ecumenism Inter-Religous dialogue and peace education. Calabar: Kenjoel Business Enterprise,

[27] Chima, Aja M. Interviewed on 13/1/2011 born on 6th August, 1945.

[28] John, Okoro Egbe. Interviewed on 18/1/2018 born on 2nd February, 1945.

[29] Obaji, Obasi Alias Nwoke Ezuike. Interviewed on 12/11/2011, born on 10th Friday, 1940.

[30] Egbe Julin interviewed on 15th January, 2018 born on 6th July 1967

[31] Price Emenike Nwogo interviewed on 13th January, 2018 born 1971

[32] Chief Eyeke Nwelebe interviewed on 13th January, 2018 born on 20th January, 1932

[33] Egbe Jude interviewed on 13th January, 2018 born on 14th April, 1963. 